\title{
Tarihî Sözlüklerin Tanım ve Tanıklarında Metinlerarasılık*
}

\section{Intertextuality on The Definitions and Examples of Historical Dictionaries}

\author{
Ezgi ASLAN** (1)
}

"Bu çalışma, Hacettepe Üniversitesi, Sözlük Bilim Uygulama ve Araștırma Merkezi tarafindan 17-19 Eylül 2018 tarihinde düzenlenen IV. Uluslararası Sözlükbilimi Sempozyumu'nda aynı başlıkla sunulmuş olan bildirinin gözden geçirilmiş ve genişletilmiş biçimidir.

\section{ORCID: E.A. 0000-0002-0638-280X}

"Sorumlu yazar/Corresponding author: Ezgi Aslan (Dr.),

Anadolu Üniversitesi, Eskişehir, Türkiye

E-posta: ezgicorga@anadolu.edu.tr

Başvuru/Submitted: 01.07.2020 Kabul/Accepted: 20.07 .2020

Atıf/Citation: Aslan, A. (2020). Tarihî sözlüklerin tanım ve tanıklarında metinlerarasılık. Dilbilim Dergisi - Journal of Linguistics, 35, 15-26. https://doi.org/10.26650/jol.2020.007

\section{öz}

Sözlüklerin her biri kendinden önce yazılan sözlüklerden etkilendiği gibi kendinden sonra yazılacak sözlükleri de etkiler. Sözlükler aynı ya da benzer amaç için önceden yazılmış sözlüklerle benzer dil malzemesini ve yapıları kullanırlar. Edebiyattaki metinlerarasılıkta her bir söylem başka bir söylemi yeniler ve her edebî metin de önceki metinleri az çok tekrar eder. Sözlükleri derleyenler de diğer sözlüklerdeki çalışmalardan belirli ölçüde yararlanırlar. Sözlüklerde metinlerarasılığın düzeyinin ne olacağı, bir sözlüğün diğer sözlüklerden ne kadar etkilenebileceği ya da sözlüklerde neyin 'metinlerarasılık' ve neyin 'telif hakkı'ile ilgili olacağı konusunda kesin bir görüş bulunmamaktadır. Bu konuyla ilgili çalışmalar daha çok telif hakkı ve etikle ilgilidir. Bu çalışmada, sözlüklerdeki tanım ya da tanıkların birbirine benzemesi ya da yeni bir sözlük hazırlanırken önceki sözlüklerin tanım ya da tanıklarının bire bir ya da kısmen kopyalanmasının bir telif sorunu olup olmadığı, benzerliklerin ya da aynııkların metinlerarasılık olarak kabul edilip edilemeyeceği konusu tartışılacak ve konu, tarihî sözlüklerden hareketle eş zamanlı olarak Eser-i Şevket adlı tarihî sözlük özelinde irdelenecektir. Anahtar kelimeler: Sözlükbilimi, Tarihî sözlük, Tarihî sözlükbilimi, Metinlerarasılık, Telif

\section{ABSTRACT}

Each dictionary affects those to be written thereafter, as well as being influenced by those written before. Dictionaries use similar language materials. In literary texts each discourse gives way to the next, and, to a greater or lesser degree, every literary text repeats what has previously been written. There is no definite opinion on the level of intertextuality between dictionaries, on the extent to which a dictionary can be influenced by other dictionaries, nor on what 'intertextuality' in dictionaries is, and what is related to 'copyright'. Studies related to this topic are typically more concerned with copyright and ethics. This study deals with issues such as the extent to which definitions in dictionaries are similar to each other, the timing of the preparation of a new dictionary, whether the copying-in whole or in part - of individual definitions given in previous dictionaries is a copyright issue, and whether similarities or differences should be accepted as intertextuality. This subject will be examined from the perspective of historical dictionaries.

Keywords: Lexicography, Historical dictionaries, Historical lexicography, Intertextuality, Copyright 


\section{Giriş}

Kilgarriff (2013: 77)'e göre sözlük yazmanın üç yolu vardır:

- Kopyalama (copy)

- İçözlem yapma (introspect)

- Veriye bakma (look at data)

Kilgarriff, önceki sözlükleri kontrol etmenin sözlükbilimsel süreçte göz ardı edilmemesi gereken bir adım olduğunu belirtir ancak hazırlanan sözlüğün özgün bir çalışma olması isteniyorsa bu adımın ikincil bir adım olması gerektiğini vurgular. İçgözlem yapma yani sezgiyle hareket etme, sözlük hazırlarken her an gereklidir ancak sözlük hazırlayıcısı yalnızca içgözlemle yola çıkarak hata yapabilir ya da bazı bilgiler eksik kalabilir. Büyük bir veri koleksiyonunun (sözlü ya da yazılı) yani derlemin ise sözlük hazırlamayı birçok yönden desteklediğini belirtir (2013: 77-78).

Seçilen maddebaşlarının tanım ve tanıklanması; sözlükler hazırlanmaya başlanmadan önce titizlikle planlanması gereken ve sözlüğün hedef kitlesi ve amacına göre farklılık gösteren bir aşamadır. Bu aşamada, sözlükteki maddebaşlarının nasıl tanımlanacağı ve tanıklanacağı bilimsel ölçütlerle ne kadar desteklenirse sözlügün kalitesi de o oranda artacaktır. ${ }^{1}$ Günümüzde sözlük hazırlamada kullanılan geniş derlemlerin 1980'lerin başında tasarlandığı düşünülürse (Atkins ve Rundell, 2008: 53) 19. yüzyılda hazırlanmış sözlüklerde bu yolu kullanmanın mümkün olmadığı aşikârdır. Zgusta’ya göre -eğer varsa- söz konusu dilde (ya da türde) hazırlanmış diğer sözlükler de önemli bir bilgi kaynağı olabilir. Bazen bir sözlük, başka bir sözlüğün derlenmesinin temeli olabilir ya da tek dilli bir sözlük, iki dilli bir sözlüğün kaynak dilinin ögelerini açıklamak için kullanılabilir (1971: 239). Zgusta’ya göre bu yöntem nadirdir ancak tarihî sözlükler söz konusu olduğunda bunun çok daha sık yapıldığı görülmektedir.

Tarihî sözlüklerde maddebaşlarının nasıl tanımlanıp tanıklandığına dair bilgi edinmek için yararlanılabilecek çok az kaynak vardır. Sözlüğün yazarıyla görüşmek söz konusu değildir. Sözlügüun ön sözünde bu bilgi verilmiş olabilir veya dönemin genel kaynaklarına dair bir araştırma yapılarak bilgi sahibi olunabilir. Tanzimat Dönemi sözlüklerinde de kendisinden önce yazılmış olan sözlükler, yeni yazılan sözlüklere kaynaklık etmiş hatta adeta bu sözlükler derlem olarak görülmüştür.

\section{Metinlerarasılık}

Charles Grivel'e göre "Hiçbir metin tek başına var olmaz, her metin her zaman bir 'metinler evreni' ile bağlantılıdır (Grievel 1978'den akt. Plett, 1991: 17). Dolayısıyla metinlerarası bakış açısına göre bir metin ele alındığında o metinden önce yazılanlarla metin arasındaki bağlantıyı koparmak mümkün değildir. Aktulum'un da belirttiği gibi önceleri metinler çoğunlukla tarihe, yazara, yazarın psikolojisine ve amaçlarına göre ele alınıyordu. Ancak sonradan söylemlerin iç içe geçtikleri, yapıtların üst üste gelerek birbirleriyle karıştıkları, her yazınsal metnin aslında

1 Tanım konusunda geniş bilgi için bk. (Gökter Gençer, 2018). 
“çok sesli” özellikte olduğu, metnin ve anlamın büyük ölçüde önceki metinlerden gelen kesitlerin iç içe geçmelerine bağlı olarak üretildiği savı ileri sürülerek yeni bir metin tanımı ve anlayışı ortaya kondu (2000: 7-8). Yeni bir metin ortaya çıktığında metnin önceki metinlerle ilişki hâlinde olduğu ve ardıl metinlerin de öncüsü olduğu (Plett, 1991: 17) düşüncesi benimsendi.

Günümüzde metinlerarasılık (intertextuality) kavramı edebiyatla ilgili bir kavram olmaktan çıkmış, postmodernizmle birlikte tüm diğer sanat dallarında da etkisini göstermiştir. Dolayısıyla resim, heykel, mimari, sinema vb. sanat dallarında da var olan bir olgu olarak görülmektedir. Aktulum'a göre başka ülkelere ait yazarların eserlerinin çevrilmesi ile karşılaştırmalı yazın incelemeleri, aynı biçimde bilimlerarası alışverişler de çoğalmış; özellikle bilim, felsefe, yazın vb. alanlar arasında alışverişe oldukça fazla rastlanmıştır (2000: 10). Elbette bu alışverişin sözlükbilim alanında görülmesi de mümkündür.

\section{Sözlüklerde Metinlerarasılık ve Telif Konusu}

Sözlüklerin her biri kendinden önce yazılan sözlüklerden etkilendiği gibi kendinden sonra yazılacak sözlükleri de etkiler. Sözlükler aynı ya da benzer amaç için önceden yazılmış sözlüklerle benzer dil malzemesini ve yapıları kullanırlar ve Svensén'ın da belirttiği gibi “Doğal olarak her yeni sözlük projesinin başında ‘tekerleği yeniden icat etmek' ve sözlükbiliminde önceden yapılan ilerlemeleri kullanmaktan kaçınmak anlamsız olur (2009: 428).” Edebiyattaki metinlerarasılıkta her bir söylem başka bir söylemi yeniler ve her edebî metin de önceki metinleri az çok tekrar eder. "Her metin açık ya da kapalı bir biçimde önceki metinlerden, yazınsal gelenekten izler taşır ve bu görüşü savunan yeni eleştiri yanlıları metinlerarasılığın 'alıntısal özelliği' ni göstermeye uğraşır (Aktulum, 2000: 18).” Sözlükleri derleyenler de diğer sözlüklerdeki çalışmalardan belirli ölçüde yararlanırlar. Svensén bunu bir "hayatta kalma içgüdüsü” olarak betimlemektedir çünkü sözlük derleyenler önemli bir şeyi gözden kaçırmamak için kendi eserleriyle ilgili tüm sözlükleri incelerler (2009: 428).

Sözlüklerde metinlerarasılığın düzeyinin ne olacağı, bir sözlüğün diğer sözlüklerden ne kadar etkilenebileceği ya da sözlüklerde neyin 'metinlerarasılık' olacağı, neyin 'telif hakkı' kapsamına gireceği konusunda kesin bir görüş bulunmamaktadır. Günümüzde bu durumun yasalarla ya da etikle düzenlenip düzenlenmediği konusu da net değildir. Uluslararası alanyazında sözlüklerde metinlerarasılık konusuyla ilgili herhangi bir çalışmaya rastlanmamıştır. ${ }^{2}$ Bu konuyla ilgili çalışmalar daha çok telif hakkı ve etikle ilgilidir. Ancak bu çalışmada ele alınan tarihî sözlüklerle ilgili, eş zamanlı bir çalışma yapıldığı için günümüz telif hakkı ve etik kurallarıyla eserin yazıldığı döneme dair çıkarımlar yapılamayacağından ve incelemenin amacına uygun olmayacağından telif konusu ile ilgili ayrıntılı bilgi verilmeyecektir. ${ }^{3}$

Edebî eserlerdeki metinlerarasılıkla sözlükbilimdeki metinlerarasılık şüphesiz ki çok farklı özellikler gösterir. Sözlüklerdeki metinlerarasılık, maddebaşları tek tek incelenmeden

2 Türkiye'de sözlüklerde metinlerarasılıkla ilgili bilinen ilk çalışma (Dinçer, 2011)'a aittir.

3 Ayrıntılı bilgi için Burchfield (1984), Spears (1987), Zgusta (1988), Hausmann (1989), Williams (1992)'a bakılabilir. 
ve başka sözlüklerle karşılaştırılmadan fark edilemez. Riffaterre’ye göre "Bir metinde metinlerarasılığın varlığını algılayamamak, metnin yapısını tam olarak çözememek anlamına gelir (akt. Aktulum, 2000: 61).” Edebî bir metindeki metinlerarasılığı bir okurun algılayabilmesi o yapıtın yazınsallığının önemli unsurlarından biri olsa da bir sözlükteki metinlerarasılığı fark etmemek o sözlüğün anlaşılamaması anlamına gelmez.

"Sözlüklerdeki metinlerarasılığı tespit etmek edebî metinlerdeki tespitten daha farklıdır. Sözlüğün başka hangi sözlüklerden alıntı yaptığının ve ne kadar alıntı yaptığının tespiti de oldukça uzun sürebilir. Bunun yanı sıra sözlükler tırnak içinde alıntı yapmaya ve yapılan alıntıyı gerek içnot ve gerekse dipnot olarak göstermeye uygun metinler değildir (Dinçer, 2011: 37-38). Sözlüğün alıntı yapıp yapmadığı ancak baş verisinde (ön söz, teşekkür ya da ithaf, içindekiler ve katkıda bulunanlar), son verisinde (kaynakça, yararlanılan eserler) ya da çapraz gönderimlerinde tespit edilebilir.

Aktulum'a göre iki ya da daha çok metin arasında kurulan “ortakbirliktelik ilişkisi” bir metne yapılan gönderge, yapıtın adı ya da yazarı açıkça bildirilerek ve alıntılanan kesitler (Ör. ayraçlar ya da italik yazı kullanılarak) belirtilerek açık ilişkiler; bir yapıtta ayrışı unsurlara yer verildiği konusunda hiçbir belirti, ipucu verilmeden kapalı ilişkiler kurulabilir. Alıntı, gönderge, açık; gizli alıntı ve anıştırma; kapalı metinlerarası ilişkilerdir (Aktulum, 2000: 93-94):

Alıntı: Bir metnin başka bir metindeki varlığını en somut biçimde görünür kılan, ilk akla gelen, en genel ve en sık karşılaşılan metinlerarası yöntemdir. Alıntıyı belirten göstergeler, -italik yazı, ayraçlar veya alıntının metindeki tümcelerden çoğu zaman belirli bir biçimde ayrı yazılması- yapıttaki ayrışıklığı somutlaştırır (Aktulum, 2000: 95). Sözlüklerde bu tür bir metinlerarasılığın kullanılması gerek zaman gerekse sayfa sayısı açısından oldukça maliyetlidir.

Gönderge: Yapıtın başlığını ya da yazarın adını anarak yapılır. Bir metinden alıntı yapılmadan, okuru doğrudan bir metne gönderir (Aktulum, 2000: 101). Bu tür açık metinlerarası ilişki sözlüklerin baş verisinde, özellikle ön sözde ya da sözlüğün son verisinde kaynakçada kurulabilir. Bunun yanı sıra sözlük dışı çapraz gönderimlerle de sözcük listesinde her bir maddede gönderge yapılabilir.

Gizli alıntı: Bir sözcenin ayraçlar ya da italik yazı kullanılmadan, sözcenin geldiği yapıt ya da yazarın adı belirtilmeden yapılan alıntıdır (Aktulum, 2000: 103). Tarihî sözlüklerde bu tür metinlerarası ilişki sık görülmektedir ve miktarını tespit etmek oldukça uzun sürebilir.

Anıştırma: Anıştırılan metin ile anıştırma yapan metin arasında bir "söyleşim"i işin içerisine sokar (Aktulum, 2000: 108-109). Bu türden kapalı ilişki daha çok edebî eserlerde görülmektedir.

\section{Metinlerarasılıkta Sık Başvurulan Önemli Tarihî Sözlükler}

Tarihî sözlüklerde, Kilgarriff' in bahsettiği sözlük yazma yöntemlerinin ilki yani kopyalama sıkça kullanılmaktadır. Ancak bu dönemdeki kopyalamanın aslında bir çeşit veriye bakma (derlem kullanımı) olduğu da söylenebilir. Tanzimat Dönemi'nin sözlüklerinde Kamus-1 Türkî’ye kadar genellikle Türkçe kökenli maddebaşlarının sıklığının çok az olduğu ve sözlük hazırlama 
sebebinin de Türkçe sözcüklerden ziyade Arapça ve Farsça kökenli sözcükleri listelemek ve okuyucuya sunmak olduğu düşünüldüğünde önceden yazılmış önemli Arapça, Farsça ve diğer dillerin sözlüklerine bakmanın ve istifade etmenin doğal olduğu söylenebilir. Önemli Arapça ve Farsça sözlüklerin Türkçeye tercümelerini takiben birçok Türkçe sözlük yazılmış ve bu sözlüklerde ise sıklıkla tercümelere başvurulmuş ve bu tercümelerden yararlanılmıştır. Türkçeye çevrilen ve Tanzimat Döneminde bir nevi derlem olarak kullanılan sözlüklerden bazıları şunlardır:

\subsection{Vankulu Lugati $(V L)^{4}$}

Vankulu Lügati ${ }^{5}$, Cevherî’nin (ö.400/1009'dan önce) kaleme aldığı ve es-Sihâh adlı meşhur Arapça sözlüğün Vankulu Mehmed Efendi (ö. 1000/1592) tarafından yapılmış tercümesidir. Eseri değerli kılan yönlerden birisi, bir Osmanlı müellifinin kaleminden çıkıp matbaada basılan ilk kitap olmasıdır. Zira eser 31 Ocak 1729 (1 Recep 1141) tarihinde İbrahim Müteferrika tarafından yayına hazırlanarak neşredilmiştir. Vankulu Mehmed Efendi, es-Sihah'ı bütünüyle karşılamak iddiasıyla ortaya çıkar ancak kaynak metni bütünüyle alıntılamaz, çeviri sırasında başka Arapça lügatlerden de yararlanarak eseri telif bir görünüme kavuşturur. Kendisinden önceki Sıhâh tercümelerinden farkını belirtir. Tercüme, 19. yy'ın ikinci yarısına kadar Osmanlı sahasında itibar edilen birkaç ilmî lügatten biri hâline gelmiştir.

\subsection{El-Okyânûsu'l-Basît Fî Tercemeti'l-Kâmûsu'l-Muhît (KM) ${ }^{6}$}

el-Okyânûsu'l-Basît ${ }^{7}$, Fîrûzâbâdî'nin (ö.1415) el-Kâmûsu'l-Muhît adlı Arapça sözlügüünün Mütercim Âsım Efendi (ö. 1819) tarafindan yapılmış tercümesidir. Arapça-Osmanlıca kaleme alınmış en önemli sözlüklerden biri olan el-Okyânûs 'l-Basît, Arapça ifadelerin tespitinde, Osmanlıca metinlerin doğru anlaşılmasında ana müracaat metni olarak görülür ve Arapça dil ve kültür servetini ve Türkçenin söz varlığını tespiti bakımından günümüzde de önemini muhafaza etmektedir. Mütercim Âsım Efendi, 1805-1810 yılları arasında tercüme ettiği elKâmûsu'l-Muhît'i hazırlarken Muhammed Murtazâ ez-Zebîdî'nin (ö. 1791) 40 ciltlik Tâcu'l'Arus şerhi dâhil olmak üzere el-Muhkem ve el- 'Ubâb gibi lügat alanındaki birçok kaynağın

4 Vankulu Lügati Prof. Dr. Mustafa Koç ve Doç. Dr. Eyyüp Tanrıverdi tarafından, İbrahim Müteferrika baskısı esas alınarak iki cilt hâlinde Türkiye Yazma Eserler Kurumu Başkanlı̆̆ Yayınları arasında 2014-2015 yıllarında yayımlanmıştır.

5 http://www.kamus.yek.gov.tr/Home/Index_?n_id=2 adresinden Vankulu Lügati ile ilgili ayrıntılı bilgiye ulaşıllabilir. (Erişim tarihi: 10.09.2018)

6 el-Okyânûsu'l-Basît Osmanlı dönemine ait pek çok yazma ve basılı nüshası bulunan el-Okyânûsu'l-Basît fî Tercemeti'l-Kâmûsu'l-Muhît'in, Süleymaniye Yazma Eser Kütüphanesi, Hamidiye Koleksiyonu 1377-1378 ve 1379 numaralarda kayıtlı, bizzat müellifinin tashih ettiği ve Sultan II. Mahmud'a takdim edilen yazma nüshası; Prof. Dr. Mustafa Koç ve Doç. Dr. Eyyüp Tanrıverdi tarafından matbu nüshalarla da karşılaştırılarak çevriyazısı yapılmış ve altı cilt halinde Türkiye Yazma Eserler Kurumu Başkanlığı Yayınları'ndan biri olarak 2013-2014 yıllarında yayımlanmıştır.

7 http://www.kamus.yek.gov.tr/Home/Index_?n_id=2 adresinden sözlükle ilgili ayrıntılı bilgiye ulaşılabilir. (Erişim tarihi: 10.09.2018) 
yanı sıra tefsir ve hadis kitaplarını da süzerek tercümesini tamamlamış ve yazı diliyle birlikte halk ağzından da yararlanmıştır.

\subsection{Ahterî-i Kebîr $(A K)^{8}$}

Muslihiddin Mustafa b. Şemseddin Ahterî tarafindan yazılan Arapça-Türkçe bir sözlüktür. Eser, 1545 yılında telif edilmiştir. Yaklaşık 40.000 kelimeyi içeren sözlüğün çok sayıda baskısı bulunmaktadır. Eserin ilk baskısı 27 Nisan 1827 yılında Matbaa-i Âmire'de 709 sayfa olarak yapılmıştır. Mütercim Âsım Efendi’nin Kamus Tercümesi ile içerik açısından kıyaslanamaz ancak Arapça sözcükleri Arapçanın sülasi ve rübai köklerine göre değil de alfabetik sunması, çok kullanılan sözcükleri seçerek sözlüğün hacmini küçültmesi, maddebaşlarının karşılıklarını mümkün olduğu kadar Türkçe vermesi ve eş anlamlı Arapça sözcüklerle pekiştirmesi ve Arapça tanıklarla tanımı pekiştirmesi açısından önemli bir sözlüktür.

\subsection{Burhân-ı Kâtı (BK) ${ }^{9}$}

Tebrizli Hüseyin B. Halefi'nin 1652 yılında yazdığı Burhan-1 Kâtı isimli sözlüğün Türkçe tercümesidir. Mütercim Asım, eseri Tıbyan-1 Nafi der Tercüme-i Burhan-1 Kâtı adıyla Türkçeye çevirmiştir. Eserin tercümesi, Tanzimat Dönemi sözlüklerindeki Farsça kökenli maddebaşları için önemli bir derlemdir. İçerik bakımından bir özelliği; mevcut sözcüklere ve sözcüklerin anlamlarına, yararlandığı eserlerden eklemeler yapmış olmasıdır.

\section{Tarihî Sözlüklerin Tanım ve Tanıklarında Metinlerarasılık}

Tarihî sözlüklerin tanım ve tanıklarındaki metinlerarasılığın miktar ve derecesini tespit etmek, zaman ve emek açısından uzun süren bir iştir. Diğer tüm Tanzimat Dönemi sözlüklerinde de yapılabilecek bu gözlem, bu çalışmada Eser-i Şevket adlı tarihî sözlük üzerinden örneklendirilecektir.

\subsection{Eser-i Şevket (EŞ) ${ }^{10}$}

Eser-i Şevket, Mehmed Şevket es-Seyyid tarafından Divan Edebiyatı şairlerine yönelik olarak hazırlanan bir cinas sözlüğüdür. Bu yönüyle bir uzmanlık sözlüğü (specialised dictionary) sayılır. H 1268/ M 1851 tarihinde Sultan Abdülmecit Han zamanında tamamlanmış olan bu eser, ön sayfalarla birlikte toplam 7+745 sayfadır ve tek cilttir. Eser toplam 29 babdan oluşmaktadır. Her bab da fasıllara ayrılmıştır. Bablar maddebaşı sözcüğün ilk harfine göre, fasıllar ise son harfine göre düzenlenmiştir. Örneğin "Faslü'l-bâ bi’r-râ" bâ harfi ile başlayıp râ harfi ile biten maddebaşlarını göstermektedir. Eser nesir tarzında olup maddebaşları sütunlarla ayrılmamış; bütüncül yapıdaki satırlar devam ederken, parantez içinde verilmiştir.

8 Güneş (2014)'ten ayrıntılı bilgiye ulaşılabilir.

9 https://islamansiklopedisi.org.tr/burhan-i-kati\#2-burhan-i-kati-tercumesi adresinden ve Akçay (2010)'dan sözlükle ilgili ayrıntılı bilgiye ulaşılabilir. (Erişim tarihi: 10.09.2018)

10 Eser-i Şevket ile ilgili ayrıntılı bilgiye Aslan (2017)'den erişilebilir. 
Maddebaşlarında hareke kullanılmamıştır. Eserde toplam 17.472 maddebaşı bulunmaktadır. Mehmet Şevket maddebaşlarının kökenlerini de vermiştir. Onun verdiği köken bilgilerine göre 11.652 maddebaşının kökeni Arapça, 2251'i Farsça ve 1388'i ise Türkçe kökenlidir. 2119 maddebaşının kökeni verilmemiştir. Kökeni verilmeyen bu maddebaşlarının dilbilgisel bilgileri kontrol edildiğinde ise bu maddelerdeki sözcüklerin çoğunun Arapça çekimli ad ya da eylem olduğu görülmektedir. Bunun yanı sıra 62 maddebaşı Batı kökenli (Ecnebî) ve Çerkes, Ermenî, İbranî, Mısır, Rumî ve Yunanî kökenli kelimelerdir. Ayrıca maddelerin bir kısmında da Türkî ve Arabî, Türkî ve Farsî, Farisîden muarreb (Arapçalaşmış) gibi bilgiler de verilmiştir. Sözlükteki tanımların hemen hemen tümü Türkçedir. Tanımlarda kullanılan Türkçe oldukça sade ve anlaşılırdır.

\subsection{Eser-i Şevket'te Metinlerarasılık}

Eser-i Şevket'te hattî cinaslı maddebaşlarını listelemek temel amaç olduğundan daha uzun tanımlar yerine kısa tanımlar tercih edilmiştir. Aktulum (2000)' da verilen sınıflandırmaya göre EŞ'de 54 maddede gönderge bulunmaktadır. Gönderge yapılan maddelerde verilen tanımlar belirtildiği gibi kısa tutulmuş, "tafsili ... mesturdur." kalıbı ile ilgili sözlüğe sözlük dışı çapraz gönderim (dictionary-external cross-reference) yapılmıştır (Tablo 1.):

Tablo 1: EŞ'de Kâmûsü'l-Muhit'e Gönderge

\begin{tabular}{|l|c|c|c|c|c|}
\hline Maddebaşı & Arap Harfli Yazımı & Sesletim & Kökeni & Tanım & S. \\
\hline òabù & خب̀ & $\begin{array}{c}\text { bi-fethi'l-hî ve } \\
\text { sükûnü'l-bâ }\end{array}$ & Arabî & $\begin{array}{c}\text { Şiddetle vurmak } \\
\text { manasına. Tafsîli } \\
\text { Kâmûs'ta mesturdur. }\end{array}$ & 247 \\
\hline
\end{tabular}

Aynı maddebaşı Mütercim Asım'ın KM tercümesinden kontrol edildiğinde EŞ’ye maddenin çok kısa bir tanımının KM'den alındığı ve daha ayrıntılı bilgi alabilmek için de çapraz gönderimle bu eserin adının “Tafsili Kâmûs'ta mesturdur.” biçiminde verildiği görülür (Resim 1.)"

11 http://www.kamus.yek.gov.tr/ adlı internet adresinden 25.03.2017'de erişilmiştir. 


\begin{tabular}{|c|c|}
\hline Arapça Yazilsg & 曲曲 \\
\hline - & >بط \\
\hline Arapça Okunuş & \\
\hline el-habt & - \\
\hline
\end{tabular}

\title{
Kâmûsu'HMuhît Tercümesi Sözlügüünde Bulunan Açıklama
}

\begin{abstract}
[el-bab t ] (bāân ve bā'nun sükūnuyla) Şiddetle vurmak

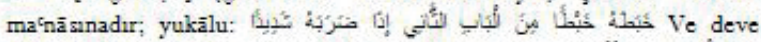

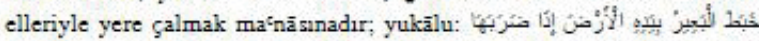

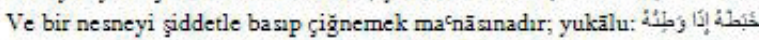
1 Ve önüne her kim räst gelirse kulıç ile çalıp dövmek macnāsına

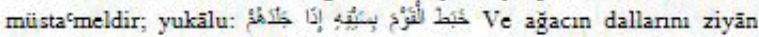
olmamak için bağladıktan sonra sırık ile yapraklann silkmek

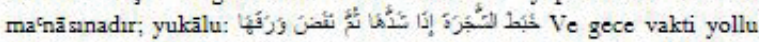
yolsuz kör gidişi gibi görülmeden nere gelirse basarak yürüyüp gitmek

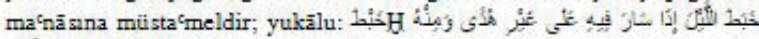
¿

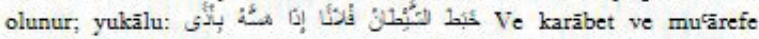
makūlesi vesile yok iken bir adamdan ihsān taleb eylemek ma'nāsına

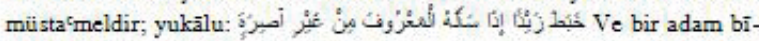
karābet ihsān isteyen kimseye îsān eylemek ma'nā sınadır; yukālu: فئَ

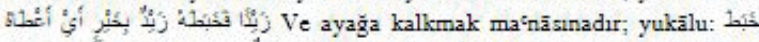

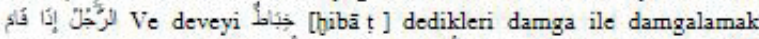

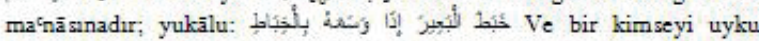
basmakla uyumak için nere olursa olsun hemān kendisini oraya bırakıp

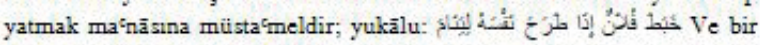
adam bir kimseye bì-vesīle-i mu'ärefe incam eylemek ma'nāsınadır;

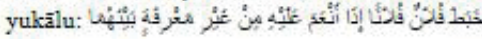

Resim 1. KM'de “òabù” Maddesi

Gönderge yapılan bir diğer sözlük de Burhân-1 Kâtı (BK)'dır. Burada da aynı söz kalıbı kullanılmış ve EŞ'de tanım kısa tutularak ilgili sözlüğe gönderge ya da sözlük dışı çapraz gönderim yapılmıştır:

Tablo 2: EŞ'de Burhân-1 Kâtı'ya Gönderge

\begin{tabular}{|l|c|c|c|c|c|}
\hline Maddebaşı & $\begin{array}{c}\text { Arap Harfli } \\
\text { Yazımı }\end{array}$ & Sesletim Bilgisi & Kökeni & Tanımı & S. \\
\hline Àreş & bi-meddi'l-elif & & $\begin{array}{c}\text { İanlı bir kemankeş adıdır. } \\
\text { Ok attı̆̆ vakitte kırk } \\
\text { merhale yere düşürürdü. } \\
\text { Tafsili Burhân-ı Kâtı'da } \\
\text { mesturdur. }\end{array}$ & $\mathbf{4 0}$ \\
\hline
\end{tabular}




\section{âreş (آرش) Feth-i râ ve sükûn-i şin-i} mu'cemeyle. Bir İranî kemankeş adıdır. Minûçihr silâhtarıdır. Tîr-endâzlık fenninde mahareti şu derecedeydi ki bir oku kırk merhale yere düşürdü. Gerçi pehlivân-1 merkum zatında mahir ve bî-nazir tîr-endâzdı, lâkin o ok sanata mebniydi. Nakillerine göre oku ibtida oyup mücevvef eyledikten sonra derununu jaleyle doldurup tulu'-i âfitâbda Âmul şehrinden şark tarafina doğru attı. Câzibe-i âfitâbla ta Merv şehrine düştü ki mabeyni kırk konak mesafedir. Keykubad'ın ikinci oğlunun adı dahi Âreş'ti. Key izafesiyle Keyâreş derlerdi. Kesr-i râ ilè

Resim 2. BK' da âreş maddesi

EŞ'de tanıklarda da doğrudan alıntı yapılmıştır. Toplam 120 maddede örnek kullanılmış, örneklerin çoğunluğu KM'den ya da AK'den alınmıştır. Örnekler Arapçadır ve "yukâlû" söz kalıbı kullanılarak belirtilmiştir. Yazar elif harfinde sözlükte çok fazla örneğe yer verdiyse de sonraki harflerde örnek vermekten vazgeçmiştir. Bunun iki nedeni olabilir; sözlüğün türüne göre örnek vermeye gerek görmemek ve sayfa sayısından tasarruf etmek (Tablo 3):

Tablo 3: EŞ'de Örneklerde KM'den Alıntı

\begin{tabular}{|c|c|c|c|c|c|}
\hline Maddebaşı & $\begin{array}{c}\text { Arap Harfli } \\
\text { Yazımı }\end{array}$ & Sesletim Bilgisi & Tanımı & Örnek & S. \\
\hline ükül & اكل - ال & $\begin{array}{c}\text { bi-zammi'l-elif } \\
\text { ve'l-kef }\end{array}$ & $\begin{array}{c}\text { Şol nesne } \\
\text { ki ekl } \\
\text { olunur. }\end{array}$ & 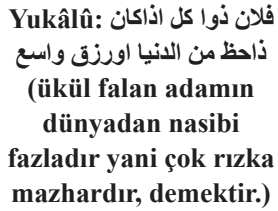 & 40 \\
\hline
\end{tabular}




\section{ükül (اكل) bi-zammi'l-hemze ve'l-kâf. Şu nesne ki ekl olunur ola; " ما يؤكل (Yenilen ويقال فلان ذو اكل اذاكان ذا، "

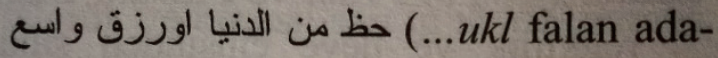 mın dünyadan nasibi fazladır yani çok rızka mazhardır, demektir.)".}

Resim 3. AK'de ükül maddesi

Bu yöntemin kullanıldığı maddelerde şüphesiz ki alıntı yapma, metinlerarası bağlantı kurma ya da telif amacı güdülmemiştir ancak Mehmet Şevket' in eseri oluştururken yararlandığı diğer sözlükler hakkında bilgi sahibi olmak mümkündür. Eserin ön sözünde ya da başka herhangi bir bölümünde derleyicinin yararlandığı kaynaklardan söz edilmemiştir. Ancak eserin içindeki 54 alıntıda adı geçen sözlükler şunlardır: BK, KM, Zend ve Pâzend Lügati, Sistan Lügati ve Ezidi Lügati. Derleyici yararlandığı sözlüklerden bahsederken eserin ön sözünde “...hazırlanırken güvenilir sözlüklerden iyice araştırıp inceleyerek... ” diye belirtmiştir ancak yazıldığı türün ilk örneği olmasından dolayı EŞ'de sözlük hazırlayıcısı, kendisinden önce yazılan aynı türdeki sözlüklerden değil, yazıldığı dönemin önemli genel amaçlı sözlüklerinden yararlanmıştır. Eser gerek maddebaşlarının düzenlenmesi ve gerekse türü ve kullanıcı kitlesi bakımından telif ve özgün bir sözlüktür.

\section{Sonuç}

EŞ’de göndergelerin yanı sıra çok sayıda gizli alıntı ve anıştırma da bulunmaktadır. Bu çalışmada gizli alıntı ve anıştırmalarla ilgili istatistiksel herhangi bir veri toplanmamış olup eserin çevriyazısı yapılırken yukarıda adı geçen eserlerden yararlanıldığı tespit edilmiştir. On dokuzuncu yüzyılda yazılan birçok tarihî sözlükte BK ve KM ve AK sırasıyla Farsça ve Arapça sözcükler için bir çeşit veri tabanı olarak görülmektedir. Özellikle Mütercim Âsım'ın'2 bu eserleri Türkçeye kazandırmasından sonra ilgili eserlerden birçok kişinin yararlandığı ve güvenilir kaynak olarak bu eserlerin uzunca bir süre kullanıldığı görülmektedir (Aksoy, 1955; Sütçü, 2013). Ayrıca EŞ’deki gizli alıntı ve anıştırmalarda kullanıcı ve sözlügün türüne göre bir tür ve bağlam değişikliği söz konusudur. Bahsi geçen KM, Arapça-Türkçe iki dilli sözlük; BK ise Farsça-Türkçe iki dilli sözlüktür. EŞ ise bir uzmanlık sözlüğüdür (cinas sözlüğü) ve Arapça ve Farsçanın yanı sıra Türkçe ve daha birçok dilde maddebaşına sahiptir. Dolayısıyla bu sözlük farklı bir türde ve farklı bir amaç için hazırlanmış olup EŞ’nin bu eserlerin bire bir kopyası olduğu söylenemez ancak metinlerarasılık da yadsınamaz.

Sözlükler arası alışveriş ya da metinlerarasılık, yabancı kaynaklarda da belirtildiği gibi

12 Mütercim Asım Efendi ile ilgili ayrıntılı bilgiye (Karslı, 2000)'dan ulaşılabilir. 
doğal olan hatta olması gereken bir adımdır ancak günümüz sözlükleri için düşünüldüğünde alışverişin derecesi tartışmalıdır. Eğer bir alışveriş söz konusuysa bu alışveriş ön söz, teşekkür ya da ithaf, içindekiler ve katkıda bulunanlar gibi baş veri bölümlerinde ya da kaynakça, yararlanılan eserler vb. gibi son veri bölümlerinde mutlaka belirtilmelidir. Bundan başka hazırlanan yeni sözlük; yararlanılan sözlüklere göre tür ve işlev, kullanıcı kitlesi, yazılış amacı bakımından farklılık göstererek telif hâle getirilebilir.

Hakem Değerlendirmesi: Dış bağımsız.

Çıkar Çatışması: Yazar çıkar çatışması bildirmemiştir.

Finansal Destek: Yazar bu çalışma için finansal destek almadığını beyan etmiştir.

Peer-review: Externally peer-reviewed.

Conflict of Interest: The author has no conflict of interest to declare.

Grant Support: The author declared that this study has received no financial support.

\section{Kaynakça/References}

Âhterî, M. E. (2009), Ahterî-i Kebîr (Haz. Ahmet Kırkkılıç, Yusuf Sancak). Ankara: TDK.

Aksoy, Ö. Â. (1955), Mütercim Âsım'a Dair Notlar, Türk Dili Dil ve Edebiyat Dergisi C. 5 S. 50, ss. 101-103.

Aktulum, K. (2000), Metinlerarası İlişkiler. Ankara: Öteki Yayınevi.

Alparslan, Y. \& Alıcı, L. (2015), Eser-i Şevket-Tıpkıbasım. Kahramanmaraş: Noya Medya.

Âsım, M. (2000), Terceme-i Burhân-ı Kâtı (Haz. Derya Örs, Mürsel Öztürk). Ankara: TDK.

Âsım, M. (2013), el-Okyânûsu'l-Basît fỉ Tercemeti 'l-Kâmûsu'l-Muhît (Haz. Mustafa Koç, Eyyüp

Tanrıverdi). İstanbul: Yazma Eserler Kurumu.

Aslan, E. (2017), Sözlükbilimsel İnceleme Yöntemi: Eser-i Şevket Örneği, Turkish Studies $\quad$ International Periodical for the Languages, Literature and History of Turkish or Turkic, S. 12/30, ss. 35-70.

Atkins, S. \& Rundell, M. (2008), The Oxford Guide to Practical Lexicography. New York: $\quad$ Oxford Press.

Burchfield, R. W. (1984), Dictionaries New and Old: Who Plagiarises, Whom, Why and When?, Encounter, C: 63 , No: 3, ss. 11-21.

Dinçer, Ş. (2011), Sözlükbirimlerin Oluşturulmasına Metinlerarası İlişkiler Bağlamında Bir Bakış Denemesi, Dil ve Edebiyat Araştırmaları Dergisi, No: 4, ss. 31-39.

Gökter Gençer, B. (2018), Tek Dilli Genel Sözlüklerde Tanım, Ankara Üniversitesi Sosyal Bilimler Enstitüsü (Yayımlanmamış Doktora Tezi), Ankara.

Güneş, M. (2014), Mustafa Ahterî Efendi ve Ahterî-i Kebîr Adlı Sözlüğü Üzerine, Dumlupınar Üniversitesi Sosyal Bilimler Dergisi, Kütahya Özel Sayısı Kasım 2014, ss. 33-38.

Hausmann, F. J. (1989), Dictionary Criminality. F.J. Hausmann et all (eds.) ss. 97-101.

Karsl1, İ. (2000), Mütercim Ahmet Asım Efendi ve Arap Lügatçiliğindeki Yeri, Atatürk Üniversitesi, Sosyal Bilimler Enstitüsü, (Yayınlanmamış Doktora Tezi), Erzurum.

Kilgarriff, A. (2013), Using Corpora as Data Sources for Dictionaries, The Bloomsbury Companion to Lexicography, Editor: E. H. Jackson, Bloomsbury Publication, London, ss. 77-96.

Mehmed Şevket es-Seyyid (1851), Eser-i Şevket. İstanbul: Matbaa-i Amire. 
Plett, H. F. (1991), Intertextuality. New York: Walter de Gruyter.

Spears, R. A. (1987), Piracy in Argot Dictionaries, Dictionaries, No: 9, ss. 124-132.

Sütçü, T. (2013), Türkçe Sözlükçülük Tarihinde Mütercim Âsım ve Kâmûs Tercümesi, Tarih Okulu Dergisi, No: 16, ss. 541-553.

Svensén, B. (2009), A Handbook of Lexicography (The Theory and Practice of Dictionary-Making). New York: Cambridge University Press.

Vankulu Mehmed Efendi (2014), Vankulu Lügati, (Haz. Mustafa Koç, Eyyüp Tanrıverdi). İstanbul: Yazma Eserler Kurumu.

Williams, J. (1992), The Question of Plagiarism and Breach of Copyright in the Dictionary-Making Process (with particular reference to the UK), Euralex '92 Proceedings, Tampere, Department of Translation Studies, University of Tampere, Department of Translation Studies, Tampere.

Zgusta, L. (1971), Manual of Lexicography. Walter de Gruyter.

Zgusta, L. (1988), Copying in Lexicography: Monier Williams Sanskrit Dictionary and Other Cases, Lexicographica International Annual, No: 4, ss. 145-164. 